\title{
Explaining Career Satisfaction on the Basis of Alumni Satisfaction, Gap Period and Gender: Evidence from Turkish Higher Education
}

\author{
Aygül Turan ${ }^{1}$, Ayşegül Özbebek Tunç² \& Esra Aydın Göktepe ${ }^{3}$ \\ ${ }^{1}$ Economic and Administrative Programs, Yildiz Technical University, Istanbul, Turkey \\ ${ }^{2}$ Department of Business Administration, Istanbul University, Istanbul, Turkey \\ ${ }^{3}$ Department of Business Administration, Istanbul Arel University, Istanbul, Turkey \\ Correspondence: Aygül Turan, Economic and Administrative Programs, Yildiz Technical University, Istanbul, \\ Turkey. E-mail: ayturan@yildiz.edu.tr
}

Received: May 29, 2015 Accepted: July 17, 2015 Online Published: August 18, 2015

doi:10.5539/ass.v11n24p229 URL: http://dx.doi.org/10.5539/ass.v11n24p229

\begin{abstract}
Despite all the ink split and words spoken, career satisfaction concept has not been evaluated sufficiently in some research areas, notably education and alumni literature. We aim to explain career satisfaction extending for individuals' university education satisfaction, alumni satisfaction, unlike the previous studies. This paper also aims to shed light on differences in alumni satisfaction and career satisfaction in terms of employees' demographic characteristics. Furthermore, we design a model in order to explain individuals' career satisfaction associating with their alumni satisfaction, gap period and gender. In order to test the hypotheses, we draw a sample of 963 respondents graduated from a public university in Turkey. Linear regression analysis results indicate that alumni satisfaction explains significant level of career satisfaction. The explaining value is remarkable to turn researchers' attention to investigate this field. In addition, alumni satisfaction scores show that there are significant differences in alumni satisfaction based upon age and gap period. Career satisfaction scores also indicate that there are significant difference in career satisfaction in terms of gender, occupation and gap period, as seen in t-test and ANOVA results. Finally, according to ordinal logistic regression analysis results, individuals having higher degree of alumni satisfaction are 4.56 times likely to get upper level career satisfaction than individuals having relatively low degree of alumni satisfaction. Moreover, individuals getting a job in two years after graduated from university are 3.97 times likely to get satisfaction from their career than those getting a job two years later after graduated from university. In addition, males are 1.74 times more likely to get higher satisfaction from their career than females. So the present research contributes a literature gap about satisfaction of alumni and career fields.
\end{abstract}

Keywords: satisfaction, career, alumni, ordinal logistic regression

\section{Introduction}

Satisfaction is one of the important issues in almost every field in both theoretically and practically. Organizations consider their customers, states care about their citizens, and similarly universities have time for their students. Many scholars are interested in this issue by studying on its antecedents, measurement, dimensions and implications. In general, satisfaction means that what people expect from something/somewhere (Abbasi et al., 2011). In other words, if someone feels pleasure about that stem from comparing a thing's performance to its expectation, we can say that this person can be satisfied (Parasuraman et al., 1988). Job satisfaction is particularly known and interested side of this field. Mostly scholars argue that an employee may satisfy about monetary and non-monetary returns from his/her job (Cabrera et al., 2008).

However, in this study, we focus on the satisfaction concept in the context of higher education because of that our objective is to create some assumptions about alumni satisfaction. When a student graduates from a university, s/he would like to have some skills that require for job search and placement (Shirai et al., 2013). Some of these skills are knowledge, communication, problem solving, critical thinking, leadership, etc. So these skills will probably contribute his/her career development and satisfaction with career in the future. On that framework, it could be easily seen that career satisfaction is explained employees' academic competence and early career success (Dierendonck \& Van der Gaast, 2013) as well as higher education satisfaction in other words 
alumni satisfaction.

\section{Conceptual Framework and Hypotheses Development}

\subsection{Alumni Satisfaction}

Understanding the dimensions of alumni satisfaction is a vital for developing educational outcomes and success criteria and evaluating academic programs (Pike, 1994; Hartman \& Schmidt, 1995; Pascarella \& Terenzini, 2005). And also it is pivotal to find an answer to the question of "why is important to understand alumni satisfaction?" Some scholars have tried to explain some reasons such as helping educational institutions financially; being involved to them, providing positive word of mouth communication and supplying jobs (Enis, 1977; Hampton, 1983). Moreover, information from alumni surveys is used to inform fundraising, college marketing, employment preparation, return on public investment, and institutional accountability such as accreditation, program review, and performance funding (Erwin, 2012).

Alumni surveys have been spreading rapidly in academic field since 1979. Pace (1979) compiled studies from 1937 to 1976 and concluded that most studies focus on competencies acquired in college than alumni outcomes. Pace (1979) reported that most of alumni believed that their college educations were relevant to their jobs. After 1980s, it was observed the contrast of this aspect (Cabrera et al., 2003). Researchers at Ohio University have used an alumni survey in 1980s. The survey includes employment status, job satisfaction, the relevance of college experiences, etc. The result from this research was that most alumni were satisfied with their college and jobs. Also Pike (1993) found that alumni job satisfaction was positively correlated with satisfaction with the college. Feldman and Newcomb (1973), Lenning (1977), and Pascarella and Terenzini (1991) studied on relationship between student learning experiences and their development and satisfaction (Abbasi et al., 2011). Results from these studies are positive relations between these concepts (Pike, 1993). In addition to them, Gaier (2005) investigated the relationship between alumni satisfaction and alumni involvement (giving). According to his research, more satisfied alumni with academic experiences results in more likely to be involved with the college.

Scholars have tried to measure alumni satisfaction in terms of several determinants. Some of them have suggested that alumni satisfaction is a beneficial tool to have an idea about the effect of the universities on students (Pike, 1994; Pace, 1979). According to these studies, intellectual and personal developments were among key satisfaction outcomes (Umbach \& Porter, 2002). In another study, alumni satisfaction with higher education was explained by a theoretical model includes performance-related outcomes-satisfaction relationships Intellectual environment and career preparation were handled as antecedents of alumni satisfaction in Hartman and Schmidt's study (1995). Pascarella and Terenzini (1978) indicated that there are two particular outcomes of college -intellectual development and personal development-. According to previous studies, both individual and environmental factors affect student and alumni satisfaction.

\subsection{Career Satisfaction}

Careers have been defined as a window through which we can see how individuals' choices are interacted with developments in society, organizations, and personal lives (Moen \& Han, 2001). In terms of role theory, career is defined as a set of occupational experiences and roles that make up one's working life (Schein, 1975). Another definition of career is the combination and sequence of roles (pupil or student, leisure, citizen, worker, spouse, parent, and other work or social roles) played by a person during the course of a lifetime (Super, 1980). Companies to keep employees in organization use the concept of career. Returning the literature, the construct was put forth by Roe (1956) and contributed by Super (1957) and Tiedeman and O'Hara (1963). In recently career literature, the keywords of career are career flexibility (Donnelly, 2015), life-long term learning (O'Neill et al, 2015; Fletcher et. al, 2010), skills (Itani et al., 2015), affairs are referred to as network and matrix organization structures or projects. (Sullivian et al. 2006) Therefore, activities after graduation by universities are important and required on individuals' life-long term learning and establishing network. Before describing career satisfaction, the difference between career and job satisfaction has to be mentioned, because there is some researches indicated the relationship between alumni satisfaction and job satisfaction (Pike, 1993); Feldman and Newcomb (1973), Lenning (1977), Pascarella and Terenzini (1991). Career satisfaction is defined as the level of overall happiness experienced through one's choice of occupations. On the other hand, job satisfaction depends on work conditions, job location, market and on relates to one's current work situation. On that framework, it could be seen that career satisfaction -like job satisfaction- can be explained by alumni satisfaction.

Career satisfaction has been defined in many different ways. Generally, career satisfaction is the satisfaction that individuals derive from the intrinsic and extrinsic aspects of their careers, including pay, advancement, and developmental opportunities (Greenhaus et al., 1990). Career satisfaction is also based on Holland (1959) and 
Super's (1984) career choice theory, and Herzberg's (1964) dual factor theory. According to Holland (1959), career satisfaction of an employee depends on his/her experience, ability, value and achievements. Super (1984) pointed out that changes in duties, a new implementation in the organization or changes in employee's job responsibilities affect career satisfaction. Furthermore, working conditions, allocation of financial rewards workload, stress and conflicts between employees' work and family life also affect career satisfaction (Dobson et al., 2007; Mc Ginley, 2009; 14). Satisfaction is based on these factors and how employees perceive them. This view stems from Herzberg's theory that is pointed working conditions; salary and promotion are concerning organizational factors. In addition, individual factors like achievement, nature of work, recognition and development are motivator factors (Dinham \& Scott, 1997).

Career satisfaction is important for both personal and organizational performance. Also it decreases turnover rate and absence. One of the most important outputs for an organization is the workforce and organizations make highest investments to it (August \& Waltman, 2004). Using this source efficiently and effectively, it depends on the employee's desire and enthusiasm to work. Thus, organizations have to interest and give importance to their career satisfaction, if they want their employees to be efficient. (Kumudha \& Abraham, 2008). As a result, we can say that career satisfaction is an important result of career planning and career management processes. The objective of another career satisfaction study was to measure proactive personality and career success. Participants of this study were alumni of a large private Midwestern university. Result of this study showed that innovation, political knowledge, and career initiative had positive relationships with career progression (Seibert et al., 1999).

Previous studies indicate the relationship between career satisfaction and other organizational outcomes. However, the most important gap in related literature is about the relationship between alumni satisfaction and career satisfaction. Career success of individuals in relation with the organization was handled in the previous studies; nevertheless, university education and extracurricular activities' effects on alumni career has not examined, considering that occupational choice is one of the dimensions of Gutteridge's (1983) career planning model. Now that these are personal and organizational career development and this dimension is mostly affected by educational choice. As people make choices and graduate from universities, they search a job related to their educational background and they make their occupational choice. Therefore, unlike the previous research, career and education relationship has to be research in detailed. To know which criteria will influence students' choices is necessary for suppliers of educational services. Career satisfaction studies provide considerable knowledge about which services will help students achieve their goals, and which factors determine overall student satisfaction or dissatisfaction (Hartman \& Schmidt, 1995). On the basis of the researches on satisfaction of alumni and career, as mentioned before, we propose the following hypothesis:

Hypothesis 1: There is a relationship between alumni satisfaction and career satisfaction. $\left(1 \mathrm{H}_{1}: \beta \neq 0\right)$

Alumni satisfaction is differentiated according to demographic characteristics of alumnus. For instance, Pace (1979) found that women tended to be more satisfied than men (Pike, 1994). Similar to Pace (1979), Phillippi (1990) indicated that women tended to be more satisfied with college than men. Considering alumni satisfaction should investigate in terms of some demographic characteristics, we propose the following hypothesis:

Hypothesis 2: There is a significant difference in alumni satisfaction in terms of (a) gender, (b) age, (c) marital status, (d) occupation and (e) gap period. $\left(2 \mathrm{H}_{1}: \mu_{\mathrm{a}} \neq \mu_{\mathrm{b}} \neq \mu_{\mathrm{c}} \neq \mu_{\mathrm{d}} \neq \mu_{\mathrm{e}}\right)$

In August and Waltman's study (2004), work and non-work influences were examined on career satisfaction among a sample of dual-earner couples. As a result of this study, only spouse support was significantly correlated with career satisfaction for husbands and work-related influences were significantly correlated with career satisfaction for both husbands and wives. Another research investigating male and female physician career satisfaction difference indicates more females than male physicians perceive that gender influences on career advancement. In addition, female physician relatively low career satisfaction than male counterparts (Gerson et al., 2007). Different from the results of researches, Yutzie et al. (2005) examined the surgeon carrer satisfaction and found both genders satisfied with their surgical careers. So the concept of career satisfaction could be investigated according to alumni's demographic structure.

Hypothesis 3: There is a significant difference in career satisfaction in terms of (a) gender, (b) age, (c) marital status, (d) occupation and (e) gap period. $\left(3 \mathrm{H}_{1}: \mu_{\mathrm{a}} \neq \mu_{\mathrm{b}} \neq \mu_{\mathrm{c}} \neq \mu_{\mathrm{d}} \neq \mu_{\mathrm{e}}\right)$

Considering researches indicating significant relationship between alumni satisfaction and career satisfaction as well as researches showing some demographic variables explain career satisfaction, which was attained from previous research, we suggest the following hypothesis: 
Hypothesis 4: Individuals' (a) gender, (b) age, (c) marital status, (d) occupation and (e) gap period and (f) alumni satisfaction level related with career satisfaction. $\left(4 \mathrm{H} 1: \mathrm{e}^{\beta \mathrm{a}}, \mathrm{e}^{\beta \mathrm{b}}, \mathrm{e}^{\beta \mathrm{c}}, \mathrm{e}^{\beta \mathrm{d}}, \mathrm{e}^{\beta \mathrm{e}}, \mathrm{e}^{\beta \mathrm{f}} \neq 0\right)$

\section{Method}

\subsection{Participants}

In order to determine the relationship between alumni satisfaction and career satisfaction, we have collected data from alumni graduated from a public university in Turkey. The university has an Alumni Information System (AIS) archiving the alumni's information, offering a network for alumni as well as serving job and internship advertisements for its members. After the graduation, students have to register for AIS so that they can use it. AIS has 111139 members, however; only 17366 members share their contact information. Considering that population of this research is 111 139, sample size must be minimum 384 (Krejcie \& Morgan, 1970). In order to reach 384 alumni, 1000 alumni was selected randomly and sent the questionnaire to them. 971 alumni responded the questionnaire with a $\% 73$ response rate, but 963 of them are available for statistical analysis.

As seen characteristics of the alumni sample in Table 1, among 963 respondents $66 \%$ are male, $49 \%$ are between the ages of 22 and $26 ; 68 \%$ are single; $71 \%$ are engineers and $74 \%$ have got a job in 6 months since graduated from the university (gap period).

\subsection{Measurement Instruments}

The questionnaire has comprised 8 items to measure alumni satisfaction, 5 items to measure career satisfaction, 7 open ended questions to determine demographic characteristics of alumni and 1 multiple choice question to ask "what kind of things do you express your satisfaction with your university?".

As an independent variable alumni satisfaction was measured by means of different general satisfaction and alumni satisfaction scales adopted by Hartman and Schmidt (1995) who have developed the scale which inspired by Hunt (1977), Oliver (1980) and Pike's (1994) studies. Career satisfaction was measured by using Greenhaus, Parasuraman and Wormley's (1990) career satisfaction scale. We ask for respondents to grade items according to five-point scale ranges from "strongly disagree" to "strongly agree".

Table 1. Characteristics of the alumni sample

\begin{tabular}{|c|c|c|c|c|c|}
\hline Variable & Number & $(\%)$ & Variable & Number & $(\%)$ \\
\hline Gender & & & Occupation & & \\
\hline Male & 624 & $66 \%$ & Faculty of Science & 117 & $12 \%$ \\
\hline Female & 319 & $34 \%$ & Architecture/ Engineering & 667 & $71 \%$ \\
\hline Age & & & Education & 14 & $2 \%$ \\
\hline $22-26$ & 457 & $49 \%$ & Business Economics & 65 & $7 \%$ \\
\hline $26-31$ & 228 & $24 \%$ & School of Vocational Studies & 22 & $2 \%$ \\
\hline $32-39$ & 126 & $13 \%$ & Art and Design & 20 & $2 \%$ \\
\hline $40-47$ & 63 & $7 \%$ & Graduate School of Natural Sciences & 17 & $2 \%$ \\
\hline $48-56$ & 43 & $4 \%$ & Graduate School of Social Sciences & 22 & $2 \%$ \\
\hline $57-66$ & 15 & $2 \%$ & Gap Periods & & \\
\hline Up to 66 & 9 & $1 \%$ & $0-6$ month & 635 & $74 \%$ \\
\hline Marital Status & & & 7-12 month & 111 & $13 \%$ \\
\hline Single & 636 & $68 \%$ & 13-18 month & 47 & $5 \%$ \\
\hline \multirow[t]{2}{*}{ Married } & 304 & $32 \%$ & 19-24 month & 22 & $3 \%$ \\
\hline & & & Up to 24 month & 39 & $5 \%$ \\
\hline
\end{tabular}

\subsection{Data Analysis}

The correlation among variables in the scale is an essential prerequisite for the factor analysis. Therefore, KMO and Barlett's Test of Sphericity results were taken into account, before alumni satisfaction and career satisfaction scales were factor analyzed. KMO value of alumni and career satisfaction scales was 0,945 and Bartlett's Test of Sphericity is significant $(\mathrm{p}<0.05)$, so, variables in the scales was significantly correlated to factor analyzed.

Conducting a single exploratory factor analysis of alumni satisfaction and career satisfaction scales, results 
indicated that there are two separate factors that were extracted with eigenvalues of one or greater. In addition, both two factors have explained 75.9 percent of the total variance. By using the Varimax rotation method, it was obvious that alumni satisfaction scale's 8 items were settled in a factor as well as career satisfaction scales 5 items were settled in the other. So, no items were dropped from subsequent analyses, as seen in Table 2. Following the factor analysis, reliability analyses have conducted to measure internal consistency of the alumni and career satisfaction scales. Crombach Alpha values for Alumni Satisfaction Scale was found 0.95 and for Career Satisfaction Scale 0.93. These results indicated that the scales are found to be reliable to measure the concepts.

Table 2. Factor loadings

\begin{tabular}{|c|c|c|c|c|}
\hline FACTORS & $\begin{array}{l}\text { Factor } \\
\text { Loadings }\end{array}$ & Mean & $\begin{array}{l}\text { Variance exp. } \\
\qquad(\%)\end{array}$ & $\begin{array}{l}\text { Cronbach } \\
\text { Alpha }(\alpha)\end{array}$ \\
\hline Factor 1:Alumni Satisfaction (8 Items) & & 3.59 & 29.629 & 0.95 \\
\hline $\begin{array}{l}\text { AS1. I am satisfied with my decision to choose [university name] } \\
\text { for my university education. }\end{array}$ & .875 & & & \\
\hline $\begin{array}{l}\text { AS4. I think that I did the right thing when I decided to chose } \\
\text { [university name]. }\end{array}$ & .867 & & & \\
\hline $\begin{array}{l}\text { AS3. My choice to be educated at [university name] was a wise } \\
\text { one. }\end{array}$ & .866 & & & \\
\hline $\begin{array}{l}\text { AS2. If I had got a univerisity education, I would have chosen the } \\
\text { [university name] again. }\end{array}$ & .851 & & & \\
\hline $\begin{array}{l}\text { AS8. I would recommend [university name] to students interested } \\
\text { in a business career. }\end{array}$ & .803 & & & \\
\hline $\begin{array}{l}\text { AS5. My educational background gave me an advantage over } \\
\text { students from other schools on my first job. }\end{array}$ & .771 & & & \\
\hline $\begin{array}{l}\text { AS6. My educational background prepared me well for my } \\
\text { current position. }\end{array}$ & .759 & & & \\
\hline $\begin{array}{l}\text { AS7. My educational background adequately developed my } \\
\text { technical skills. }\end{array}$ & .708 & & & \\
\hline Factor 2: Career Satisfaction (5 Items) & & 3.54 & 31.621 & 0.93 \\
\hline $\begin{array}{l}\text { CS12. I am satisfied with the progress I have made toward } \\
\text { meeting my goals for advancement }\end{array}$ & .873 & & & \\
\hline $\begin{array}{l}\text { CS10. I am satisfied with the progress I have made toward } \\
\text { meeting my overall career goals. }\end{array}$ & .860 & & & \\
\hline $\begin{array}{l}\text { CS11. I am satisfied with the progress I have made toward } \\
\text { meeting my goals for income }\end{array}$ & .848 & & & \\
\hline $\begin{array}{l}\text { CS9. I am satisfied with the progress I have achieved in my } \\
\text { career. }\end{array}$ & .825 & & & \\
\hline $\begin{array}{l}\text { CS13. I am satisfied with the progress I have made toward } \\
\text { meeting my goals for the development of new skills. }\end{array}$ & .737 & & & \\
\hline \multicolumn{5}{|l|}{$\mathrm{KMO}=0.945$} \\
\hline Chi-Square Bartlett's Test $(\mathrm{p}=0.000)$ & & & & 75.975 \\
\hline
\end{tabular}

After controlling the scale reliability and consistency, we conducted correlation and linear regression analyses to attain the association between alumni satisfaction and career satisfaction. After that we investigated the differences alumni satisfaction and career satisfaction in terms of demographic characteristics of individuals with analysis of variance. In order to explain career satisfaction in detail, we transformed career satisfaction data into ordinal nature (low-medium-high) first and then we conducted logistic regression analysis between career satisfaction (ordinal) and alumni satisfaction (interval), gap period (ordinal), marital status (categorical), gender (categorical), college major (categorical) in single model. We applied Drory and Glukinos (1980) method for career satisfaction as low, middle and high level of career satisfaction of individuals. Total scores of career 
satisfaction were allocated below $\% 25$, from $\% 25$ to $\% 75$ and above $\% 75$, and entitled low, medium and high level of career satisfaction, respectively. Career satisfaction was measured 5 items and total scores changed between 5 and 25. For, career satisfaction was measures 5 items, 0 to 10 scores entitled low level career satisfaction, 11 to 19 scores as medium level career satisfaction and 20 to 25 as high level career satisfaction.

\subsection{Results}

Correlation and regression analyses are conducted to test the first hypothesis. As seen Pearson Correlation Coefficient value (0.627), there is a moderate positive relationship between alumni satisfaction and career satisfaction. In addition, the result of the regression analysis pointed out that alumni satisfaction explains $39 \%$ of variance of career satisfaction. So, the first hypothesis is supported.

Investigating whether or not there is a difference in alumni satisfaction and career satisfaction in terms of alumni's demographic characteristics, we have done variance analyses to test hypotheses 2 and hypotheses 3 . One-way between subjects ANOVA has been conducted in order to research the differentiation of alumni's satisfaction and their career satisfaction in terms of demographic characteristics (gender, age, gap period, marital status and occupation) as well as Tukey HSD Test has been done to see Post Hoc comparison between groups.

Table 3 summarizes that there are significant differences in alumni's satisfaction based upon age and gap period. Given Tukey test results, we identify the differences between groups and which groups mean scores higher. Tukey HSD test indicates that the mean score for satisfaction of alumni between the ages of 48 and 56 is higher than satisfaction of alumni between the ages of 32 and $39(4.011>3.364)$. The test also clarifies that the mean score for alumni satisfaction in terms of gap periods. That is, alumni whose gap period between 7 and 12 months have higher alumni satisfaction than alumni whose gap period 2 years and over $(3.50>2.95)$. In addition, the test indicates that the mean score for satisfaction of alumni whose gap period in the 0-6 months is higher than satisfaction of alumni whose gap period in the range 2 years and over $(3.68>2.95)$. Consequently, hypothesis 2 is partially supported in the research model.

Table 3. ANOVA test results summary

\begin{tabular}{|c|c|c|c|c|c|c|c|c|c|c|}
\hline \multirow[b]{2}{*}{ Difference } & \multicolumn{2}{|c|}{ Gender } & \multicolumn{2}{|c|}{ Age } & \multicolumn{2}{|c|}{ Gap Period } & \multicolumn{2}{|c|}{ Marital Status } & \multicolumn{2}{|c|}{ Occupation } \\
\hline & YES & $\mathrm{NO}$ & YES & $\mathrm{NO}$ & YES & NO & YES & NO & YES & $\mathrm{NO}$ \\
\hline Alumni Satisfaction & & $\mathrm{X}$ & $\mathrm{X}$ & & $\mathrm{X}$ & & & $X$ & & $\mathrm{X}$ \\
\hline Career Satisfaction & $\mathrm{X}$ & & & $X$ & $\mathrm{X}$ & & & $\mathrm{X}$ & $\mathrm{X}$ & \\
\hline
\end{tabular}

As seen in Table 3, there are significant differences in career satisfaction in terms of genders, occupations and gap periods. Tukey HSD test shows that the mean score for male's career satisfaction is higher than women's career satisfaction $(3.59>3.46)$. Another differentiation has been found in occupations, in that career satisfaction of alumni having graduate degree in faculty of education is higher than alumni having graduate degree in faculty of science $(4.0143>3.3724)$. Tukey test indicates the mean scores for career satisfaction in terms of gap periods. In other words, alumni whose gap period between 0 and 6 months have higher career satisfaction than between 13 and 18 months $(3.67>3.08)$. In addition, alumni whose gap period 2 years and over have lower career satisfaction than between 7 and 12 months, 19 and 24 months as well as 0 and 6 months $(2.95>3.46>$ $3.63>3.67)$. As a consequence, hypothesis 3 is partially supported in the research model.

Finally, we analyzed which demographic characteristics could explain individuals' career satisfaction, as indicated in hypothesis 4. Achieving these issues, we conducted ordinal logistic regression analyses career satisfaction with alumni satisfaction and demographic variables. As mentioned before career satisfaction was evaluated ordinal nature (low-medium-high) and demographic variables are categorical and ordinal as well. Research models are structured one dependent variable (career satisfaction) and all independent variable (age, gap period, marital status, gender, occupation and college major) are evaluated one single equation. Results indicated in Table 4.

Table 4 represent good fit model $\left(X^{2}(5, \mathrm{~N}=963)=295.365 ; \mathrm{p}=0.000\right)$ and Pseudo $\mathrm{R}^{2}$ values are about 0.304 and 0.373 . Results indicate that alumni satisfaction, gap period and gender are significantly relation with career satisfaction. Overall model is significant and alumni satisfaction, gap period and gender explain approximately $37 \%$ variance of career satisfaction. Parallel lines test indicates non-significant results, so we can say one equation was valid for proportional odds tests $(\mathrm{p}=0.241)$. We can interpret that for one unit decrease in alumni 
satisfaction the odds representing high level career satisfaction versus the combined middle and low level career satisfaction categories are 4.56 times greater, given that all of other variables in the model are held constant. Similarly, the odds of combined representing high and middle level career satisfaction categories versus low 4.56 times greater (test of parallel lines support this result). So, it can be said individuals having higher degree of alumni satisfaction are more likely to get upper level satisfaction from their career than individuals having relatively low degree of alumni satisfaction.

Table 4. Results of ordinal logistic regression between demographic characteristics, alumni satisfaction and career satisfaction (used logit link function)

\begin{tabular}{|c|c|c|c|c|c|c|c|}
\hline & & Variable & Estimate & $\begin{array}{c}\text { Odds }= \\
\operatorname{EXP}(\text { Est })\end{array}$ & Sig. & $\begin{array}{l}\text { Wald } \\
\text { Statis. }\end{array}$ & $\begin{array}{c}\text { Test of Parallel } \\
\text { Line (Ch.Sq/ Sig) }\end{array}$ \\
\hline MODEL & Threshold & Career Satisfaction & & & & & $6.734 / p=0.241$ \\
\hline Alumni & & (Low-Medium) & 2.619 & & 0.000 & 56.695 & \\
\hline Satisfac. & & (Medium-High) & 7.372 & & 0.000 & 248.006 & \\
\hline+ & Location & Alumni Satisfaction & 1.519 & 4.56 & 0.000 & 206.763 & \\
\hline Demog- & & Gap Period (Below 24 months) & 1.379 & 3.97 & 0.001 & 10.838 & \\
\hline raphics & & Gap Period (Above 24 months) & $0^{\mathrm{a}}$ & & & & \\
\hline$\rightarrow$ & & Gender (Man) & 0.558 & 1.74 & 0.001 & 10.513 & \\
\hline Career & & Gender (Woman) & $0^{\mathrm{a}}$ & & & & \\
\hline Satisfac. & Result & Cox\&Snell $\mathrm{R}^{2} /$ Nagelkerke $\mathrm{R}^{2}$ & & & & & $0.304 / 0.373$ \\
\hline & & $\mathrm{X}^{2}$ (Model Fit) & & & & & $295.365 ; p=0.000$ \\
\hline
\end{tabular}

${ }^{a}$ This parameter is set zero because it is redundant. Dependent variable: Career Satisfaction (Model), Independent Variables: Alumni Satisfaction, Demographics (Gap Period, Marital Status, Gender, College Major) EXP: Exponent, Est: Estimate. (Only significant results were indicated in Table. Age, marital status, occupation and college major are non-significant relationship between career satisfaction.)

In addition, the results in model in Table 4 shows males respondents 1.74 times more likely to represent high level career satisfaction with regard to middle and low level career satisfaction than female counterparts. Likewise, males are 1.74 times more likely to represent high and medium level career satisfaction with regard to low level career satisfaction than females (test of parallel lines support this result). On the other hand, marital status does not significantly explain career satisfaction $(\mathrm{p}=0.401>0.05)$ in the model.

Table 4 also indicate that one unit decrease in gap period (from above 24 months to below 24 months) the odds representing high level career satisfaction versus the combined middle and low level career satisfaction categories are 3.97 times greater, given that all of other variables in the model are held constant. Also the odds of combined high representing high and middle level career satisfaction categories versus low 3.97 times greater (test of parallel lines support this result). The results could be interpreted that individuals finding a job in 2 years after graduated from university have upper level satisfaction from their career than those finding a job following 2 years after graduated from university. Considering the impact of alumni satisfaction, gap period, marital status, gender and college major on career satisfaction as seen in Table 4, we could say hypothesis 4 is partially supported.

\section{Conclusion and Discussion}

Previous studies have examined separately some outcomes stem from alumni satisfaction (Pace, 1979; Pike, 1993; Hartman \& Schmidt, 1995; Gaier, 2005) and career satisfaction (Seibert et al., 1999; Kumudra \& Abraham, 2008). We want to handle these concepts together. For this reason, it is a pioneering research to explore relationships between alumni satisfaction and career satisfaction. The current study tested this relation for 963 alumni in the same university. As seen in results, three critical findings of this study support our hypotheses. First, we found that there is a moderate positive relationship between alumni satisfaction and career satisfaction. This result means that these two concepts are so related and need to be examined together. We try to meet this need in the related literature.

Second, there is a significant difference in alumni satisfaction in terms of age and gap period. We can comment on results regarding age in a different way. We can say that young people have more expectations from 
something such as universities, companies, lifestyles, etc. On the other hand, old people behave generally contented to something happened. So, we can think that this result can be considered as an output of this situation. As we look the gap period results, we see that newly alumni have higher satisfaction than the others. Alumni got a job in a few months have higher alumni satisfaction and also career satisfaction (it will be mentioned at below). Because job placement can positively support the perception about the university graduated. People can assume that they had good education if they get a job easily and quickly. So, they feel satisfied from the universities.

Third, there is a significant difference in career satisfaction in terms of gender, occupation and gap period. Results regarding gender, unlike previous studies, show that men have higher career satisfaction than women. There can be two reasons for this result. Firstly, YTU is a popular university especially in engineering fields and men prefer engineering faculties/departments than women in Turkey. This trend may explain why these results occur. Secondly, the men percentage of our sample is $66 \%$. When we assess career satisfaction results in terms of occupation, we see that alumni from faculty of education have higher career satisfaction than alumni from faculty of science. Lack of laboratory facilities \& equipment can be one reason of this data because it may cause the inconsistency between education and real business conditions and then affect people's career satisfaction. Besides for gap period results, we can say that there is a negative relationship between gap period and career satisfaction. When the gap period increases, career satisfaction decreases. To not get a job after graduation can make people hopeless and unsatisfied from many things including career.

Fourth, career satisfaction could be explained combined alumni satisfaction, gap period and gender. Individuals having higher degree of alumni satisfaction are more likely to get upper level career satisfaction than individuals having relatively low degree of alumni satisfaction. Moreover, individuals getting a job in two years after graduated from university are more likely to get satisfaction from their career than those getting a job two years later after graduated from university. In addition, males are more likely to get higher satisfaction from their career than females. Significant results of this overall model illustrates that satisfaction from university that individuals graduated from, whether could get a job rapidly after graduation and genders are predictors for career satisfaction. Considering that prestigious universities have made effort to integrate some companies and institutes, alumnus graduated from those could be higher satisfaction from their career.

The results and conclusions from this study need to be considered in some limitations. The major limitation of the present study is about sample. The career satisfaction data of this paper presents an overall assessment to be generalized because of career diversity among the participants of this study. However, alumni satisfaction results cannot be generalized like career satisfaction because we collected alumni data from only one university. On the other hand, career diversity could be a limitation because opportunities differentiate from one area to another. Taking the majority of sample ( $71 \%$-engineers) and scope of the sample university (technical education) are into consideration, we partially eliminate the career diversity issues. The other limitation is regarding with our model with just two variables. The model can be modified with some other variables such as alumni involvement (giving). Every limitation can be considered as a future research direction.

The results of present research contribute to universities in a different way by proposing practical implications. Universities need to develop themselves. In addition to educational improvement, this requires receiving feedback from students and alumni. Many universities conduct a survey to their students. But then alumni has disregarded by universities. This study emphasizes the importance of alumni satisfaction assessment and its relation with career satisfaction. This evaluation can contribute the prestige, popularity and preferability of universities when sharing with the public and potential students. On the other hand, the matching alumni and career satisfaction gives universities a chance to change or update the educational schedule in their faculties. So that, they can compare realized and expected education in terms of career options.

\section{References}

Abbasi, M. N., Malik, A., Chaudhry, I. S., \& Imdadullah, M. (2011). A study on student satisfaction in Pakistani Universities: The case of Bahauddin Zakariya University, Pakistan. Asian Social Sciences, 7(7), 209-219. http://dx.doi.org/10.5539/ass.v7n7p209

August, L., \& Waltman J. (2004). Culture, climate, and contribution: Career satisfaction among female faculty. Research on Higher Education, 45(2), 177-192. http://dx.doi.org/10.1023/B:RIHE.0000015694.14358.ed

Cabrera, A. F., De Vries, W., \& Anderson S. (2008). Job satisfaction among Mexican alumni: A case of incongruence between hunch-based policies and labor market demands. Higher Education, 56(6), 699-722. http://dx.doi.org/10.1007/s10734-008-9119-3 
Cabrera, A. F., Weerts, D. J., \& Zulick, B. J. (2003). Alumni survey: Three conceptualizations to alumni research. Paper presented at the Conference of Métodos de Análisis de la Inserción Laboral de Los Universitarios, The University of Leon, June 9-11, Leon, Spain, 1-108.

Dierendonck, D., \& Van der Gaast, E. (2013). Goal orientation, academic competences and early career success. Career Development International, 18(7), 694-711. http://dx.doi.org/10.1108/CDI-01-2013-0003

Dinham, S., \& Scott, C. (1997). A three domain model of teacher and scholl executive career satisfaction. Journal of Educational Administration, 36(4), 362-378. http://dx.doi.org/10.1108/09578239810211545

Dobson, R., Backman, A., \& Keegon D. (2007). Factors associated with career satisfaction among general practitioners in Canada. Canadian Journal Rural Medicine, 12(4), 217-230.

Donnelly, R. (2015). Gender, careers and flexibility in consultancies in the UK and the USA: a multi-level relational analysis. The International Journal of Human Resource Management, 26(1), 80-99. http://dx.doi.org/10.1080/09585192.2014.934889

Enis, B. M. (1977). Marketing Education in the 1980s: Strategy considerations for a mature product line. In B. A. Greenberg, \& D. N. Bellenger (Eds.), American Marketing Association Proceedings (Vol. 43, pp. 78-81).

Erwin, T. D. (2012). Intellectual college development related to alumni perceptions of personal growth. Research \& Practice in Assessment, 7(1), 41-49.

Feldman, K. A., \& Newcomb, T. M. (1973). The impact of college on students. New Jersey: Transaction Publishers.

Fletcher, M. A., Zuber-Skerritt, O., Bartlett, B., Albertyn, R., \& Kearney, J. (2010). Meta-action research on a leadership development program: A process model for life-long learning. Systemic Practice and Action Research, 23(6), 487-507. http://dx.doi.org/10.1007/s11213-010-9173-5

Gaier, S. (2005). Alumni satisfaction with their undergraduate academic experience and the impact on alumni giving and participation. International Journal of Educational Advancement, 5(4), 279-288. http://dx.doi.org/10.1057/palgrave.ijea.2140220

Gerson, L. B., Twomey, K., Hecht, G., Lee, L., McQuaid, K., Pizarro, T. T., ... Early, D. (2007). Does Gender Affect Career Satisfaction and Advancement in Gastroenterology? Results of an AGA Institute-Sponsored Survey. Gastroenterology, 132(4), 1598-1606. http://dx.doi.org/10.1053/j.gastro.2007.02.045

Greenhaus, J. H., Parasuraman, S., \& Wormly, M. (1990). Effects of race on organizational experiences, job performance evolution and career outcomes. Academy of Management Journal, 33(1), 64-86. http://dx.doi.org/10.2307/256352

Gutteridge, T. G. (1983). Linking career development and human resource planning. Washington, D.C.: Eric Clearinghouse.

Hampton, G. (1983). College student satisfaction: Marketing's approach for evaluating higher education. In P. E. Murphy (Ed.), American Marketing Association Educators' Proceedings (Vol. 49, pp. 169-173).

Hartman, D. E., \& Schmidt, S. L. (1995). Understanding student/alumni satisfaction from a consumer's perspective: The effects of institutional performance and program outcomes. Research in Higher Education, 36(2), 197-217. http://dx.doi.org/10.1007/BF02207788

Herzberg, F. (1964). The motivation-hygiene concept and problems of manpower. Personal Administration, 27(1), 3-7.

Holland, J. L. (1959). A theory of vocational choice. Journal of Counseling Psyhology, 6(1), 35-45. http://dx.doi.org/10.1037/h0040767

Hunt, K. H. (1977). CS/D overview and future research directions. In H. K. Hunt (Ed.), Conceptualization and measurement of consumer satisfaction and dissatisfaction (pp. 455-488) Cambridge, MA: Marketing Science Institute.

Itani, S., Jarlstrom, M., \& Piekkari, R. (2015). The meaning of language skills for career mobility in the new career landscape. Journal of World Business, 50(2), 368-378. http://dx.doi.org/10.1016/j.jwb.2014.08.003

Krejcie R. V., \& Morgan D. W. (1970). Determining sample size for research activities. Educational and Psychological Measurement, 30, 607-610.

Kumudha, A., \& Abraham, S. (2008). Organization career management and its impact on career satisfaction: A study in the banking sector. The Icfai University Journal of Bank Management, 7(3), 48-58. 
Lenning, O. T. (1977). Previous attempts to structure educational outcomes and outcome-related concepts: A compilation and review of the literature. Boulder: National Center for Higher Education Management Systems.

Mc Ginley, M. D. (2009). Effects of career and marriage on newlywed individuals' marital and career satisfaction (Unpublished doctoral dissertation). University of Florida, USA.

Moen, P., \& Han, P. (2001). Reframing careers: Work, family and gender. In V. M. Marchall, W. R. Heinz, H. Krueger, \& A. Verma (Eds.), Restructuring work and the life course (pp. 424-445). Toronto, Ontario: University of Toronto Press.

Oliver, R. L. (1980). A cognitive model of the antecedents and consequences of satisfaction decisions. Journal of Marketing Research, 17(4), 460-469. http://dx.doi.org/10.2307/3150499

O'Neill, T. A., Deacon, A., Larson, N. L., Hoffart, G. C., Brennan, R. W., Eggermont, M., \& Rosehart, W. (2015). Life-long learning, conscientious disposition, and longitudinal measures of academic engagement in engineering design teamwork. Learning and Individual Differences, 39, 124-131. http://dx.doi.org/10.1016/j.lindif.2015.03.022

Pace, C. R. (1979). Measuring outcomes of college. San Francisco: Jossey-Bass.

Parasuraman, A., Berry, L.L., \& Zeithaml, V. A. (1988). Servqual: A multiple item scale for measuring consumer perceptions of service quality. Journal of Retailing, 64(1), 12-40.

Pascarella, E. T., \& Terenzini, P. T. (1978). Student-faculty informal relationships and freshman year educational outcomes. Journal of Educational Research, 71(4), 183-189. http://dx.doi.org/10.1080/00220671.1978. 10885067

Pascarella, E. T., \& Terenzini, P. T. (1991). How college affects students: Findings and insights from twenty years of research. San Francisco: Jossey-Bass.

Pascarella, E. T., \& Terenzini, P. T. (2005). How college affects students: A third decade of the research (Volume 2). San Francisco: Jossey-Bass.

Phillippi, R. H. (1990). Differential item functioning on the 1988 tennessee alumni survey (Unpublished Manuscript). University of Tennessee, Knoxville, Center for Assessment Research and Development, Knoxville, TN.

Pike, G. R. (1993). The relationship between perceived learning and satisfaction with college: An alternative view. Research in Higher Education, 34(1), 23-40. http://dx.doi.org/10.1007/BF00991861

Pike, G. R. (1994). The relationship between alumni satisfaction and work experiences. Research in Higher Education, 35(1), 105-123. http://dx.doi.org/10.1007/BF02496664

Roe, A. (1956). The psychology of occupations. Hoboken, NJ, US: John Wiley \& Sons Inc. http://dx.doi.org/10.1037/13192-000

Schein, E. H. (1975). How career anchors hold executives to their career paths. Personnel, 52(33), 11-24.

Seibert, S. E., Gran, J. M., \& Kraimer, M. L. (1999). Proactive personality and career success. Journal of Applied Psychology, 84(3), 416-427. http://dx.doi.org/10.1037/0021-9010.84.3.416

Shirai, T., Shimomura, H., Kawasaki, T., Adachi, T., \& Wakamatsu, Y. (2013). Job search motivation of part-time or unemployed Japanese college graduates. International Journal for Vocational and Educational Guidance, 13, 95-114. http://dx.doi.org/10.1007/s10775-013-9241-3

Sullivan, S. E., \& Arthur, M. B. (2006). The evolution of the boundaryless career concept: Examining physical and psychological mobility. Journal of Vocational Behaviour, 69(1), 19-29. http://dx.doi.org/10.1016/j.jvb. 2005.09.001

Super, E. D. (1957). The psychology of careers (Vol. 195). New York: Harper \& Row.

Super, E. D. (1980). A life-span, life-space approach to career development. Journal of Vocational Behavior, 16(3), 282-298. http://dx.doi.org/10.1016/0001-8791(80)90056-1

Super, E. D. (1984). Career and life development. In D. Brown, \& L. Brooks (Eds.), Career choice and development. San Francisco: Jossey-Bass.

Tiedeman, D. V., \& O'Hara, R. P. (1963). Career development: Choice and adjustment. New York, NY, US: College Entrance Examination Board. 
Umbach, P. D., \& Porter, S. R. (2002). How do academic departments impact student satisfaction? Understanding the contextual effects of departments. Research in Higher Education, 43(2), 209-234. http://dx.doi.org/10.1023/A:1014471708162

Yutzie, J. D., Shellito, J. L., Helmer, S. D., \& Chang, F. C. (2005). Gender differences in general surgical careers: results of a post-residency survey. The American Journal of Surgery, 190(6), 978-983. http://dx.doi.org/10.1016/j.amjsurg.2005.08.027

\section{Copyrights}

Copyright for this article is retained by the author(s), with first publication rights granted to the journal.

This is an open-access article distributed under the terms and conditions of the Creative Commons Attribution license (http://creativecommons.org/licenses/by/3.0/). 